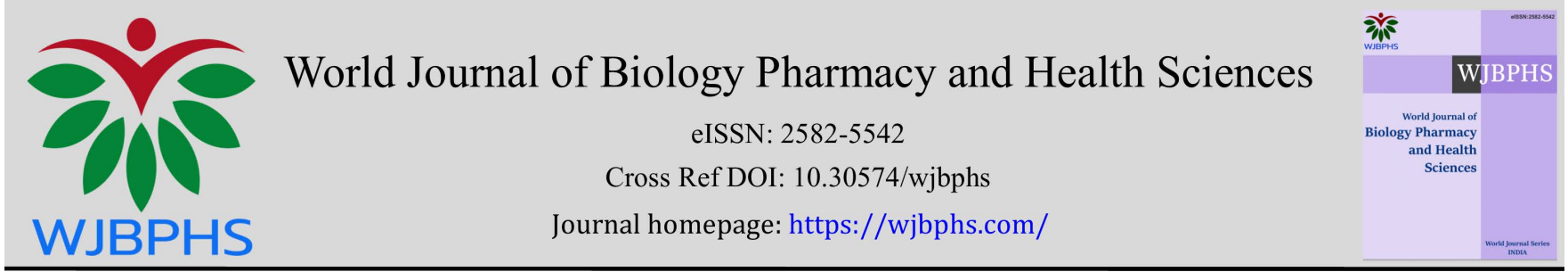

(RESEARCH ARTiCLE)

\title{
Chemical composition, antimicrobial and antioxidant activities of the essential oils from Senecio longiscapus Bojer leaves (Asteraceae)
}

Razafimaharavo Herimanana, Razafiarimanga Zara Nomentsoa, Randriamampianina Lovarintsoa Judicael, Randrianarivo Hanitra Ranjana, Rakoto Danielle Aurore Doll and Jeannoda Victor Louis *

Laboratory of Applied Biochemistry to Medical Sciences, Fundamental and Applied Biochemistry Department, Faculty of Sciences, University of Antananarivo, P. O. Box 906, Antananarivo 101, Madagascar.

World Journal of Biology Pharmacy and Health Sciences, 2021, 07(02), 009-018

Publication history: Received on 28 June 2021; revised on 02 August 2021; accepted on 04 August 2021

Article DOI: https://doi.org/10.30574/wjbphs.2021.7.2.0079

\begin{abstract}
The present work aims to study the chemical composition and the antimicrobial and antioxidant properties of the essential oil of Senecio longiscapus (SLEO) leaves. SLEO was extracted from fresh leaves by hydrodistillation with a yield of $3 \%$. It is clear, yellow, with a relative density of 0.7466 at $20^{\circ} \mathrm{C}$, a refractive index of 1.4959 , an optical rotation of $+3^{\circ} 47$, an acid number of 1.53 and an ester number of 12.49 . Gas chromatography/mass spectrometry (GC/MS) analysis of the SLEO identified 17 components, representing more than $99.09 \%$ of the overall composition. The main component of SLEO was sabinene (53.28\%) and elemicin (15\%), $\beta$-pinene (9.85\%), methyleugenol (5.58\%), $\alpha$-pinene (4.84\%) and mircene (2.37\%) were the major components. At $7.48 \mathrm{mg} /$ disk, SLEO inhibited the growth of all germs tested including four GRAM (+) and five GRAM (-) bacteria and one yeast. The zones of inhibition (ZI) ranged from $12 \mathrm{~mm}$ (Yersinia enterolitica) to $40 \mathrm{~mm}$ (Bacillus subtilis). The antioxidant activity of SLEO by the DPPH method was IC50 = 4.601 $\mu \mathrm{g} / \mathrm{ml}$. When administered orally at doses as high as $5 \mathrm{~g} / \mathrm{kg}$ body weight, SLEO was not toxic to mice. Its non-toxicity, antimicrobial and antioxidant activities could make SLEO an alternative in the treatment of infectious diseases.
\end{abstract}

Keywords: Senecio longiscapus; Essential oils; Chemical composition; Antimicrobial activity; Antioxidant activity; Toxicity

\section{Introduction}

The growing interest in essential oils is reflected in the extensive research being carried out around the world on aromatic plants. Aromatic plants produce essential oils (EO) that have great therapeutic power and interesting biological activities such as antibacterial, antifungal, larvicidal, insecticidal and antioxidant properties [1].

Asteraceae (Compositeae) is one of the plant families that are good producers of essential oils. In Madagascar, this family is represented by 550 species of which 500 are endemic [2].

Senecio is the largest and most complex genus in the family of the Asteraceae having more than 1500 species distributed widely throughout the world [3, 4]. In Madagascar, the Senecio genus is represented by 85 species and 78 of which are endemic [5]. Present in various formations in the Central Madagascar region, the Senecio genus is mainly found in open areas such as natural clearings and forest edges. The mountain environment with rocky soil is particularly favourable to its development with a rather remarkable microendemism [6].

\footnotetext{
${ }^{*}$ Corresponding author: Jeannoda Victor Louis; E-mail: victor_jeannoda@yahoo.fr

Laboratory of Applied Biochemistry to Medical Sciences, Fundamental and Applied Biochemistry Department, Faculty of Sciences, University of Antananarivo, P. O. Box 906, Antananarivo 101, Madagascar. 
The essential oils of the genus Senecio have been the subject of a large number of phytochemical studies and several biological activities have been demonstrated [7] but the studied species for essential oils constituents are still few and not more than $10 \%$ of the species belonging to this genus [8]. A number of studies have shown that several Senecio species have antimicrobial, antifungal and cytotoxic activities [3].

Many species from Senecio genus have been used in traditional medicine [8,9] and their pharmacological activities have been demonstrated: anti-inflammatory [9], antimicrobial $[10][3,8,10]$, antioxidant activities $[3,4,8,11]$, cytotoxic [8, 11] and so on.

However, nearly thirty species of Senecio, because of their high pyrrolizidine alkaloids content, are very dangerous for both humans and animals $[12,13]$. For examples, $S$. jacobaea, $S$. douglasii, $S$. riddellii caused the majority in the cattle losses in western US [12] and Senecio inaequidens was implicated in a livestock poisoning epidemic in South Africa [14].

We are interested in Senecio longiscapus which is an aromatic plant endemic to central Madagascar. According to our surveys of healers and traditional practitioners, Senecio longiscapus is used to treat sexually transmitted infections, stomach aches and intestinal parasites (vermifuge). In addition, the available literature on this plant has so far only reported botanical studies.

The main objectives of this study were to determine the composition and physicochemical characteristics of Senecio longiscapus leaf essential oil (SLEO) and to explore its potential antibacterial and antioxidant activities and toxicity.

\section{Material and methods}

\subsection{Plant materials}

Senecio longiscapus leaves constituted our study material (figure 1). The leaves were collected in February 2021 in the Amoron' i Mania region, Ambositra district, Ivony commune $\left(20^{\circ} 34^{\prime} 42.39^{\prime \prime S}\right.$; $47^{\circ} 09^{\prime} 53.01^{\prime \prime E}$, altitude $\left.1776 \mathrm{~m}\right)$ when the plant was not bearing flowers or fruits.

The plant was identified by comparison of an herbarium made from the collected material with the voucher specimen $n^{\circ} 3553$ of the Botanical and Zoological Park of Tsimbazaza (Antananarivo) made by Hildebrandt in 1933.

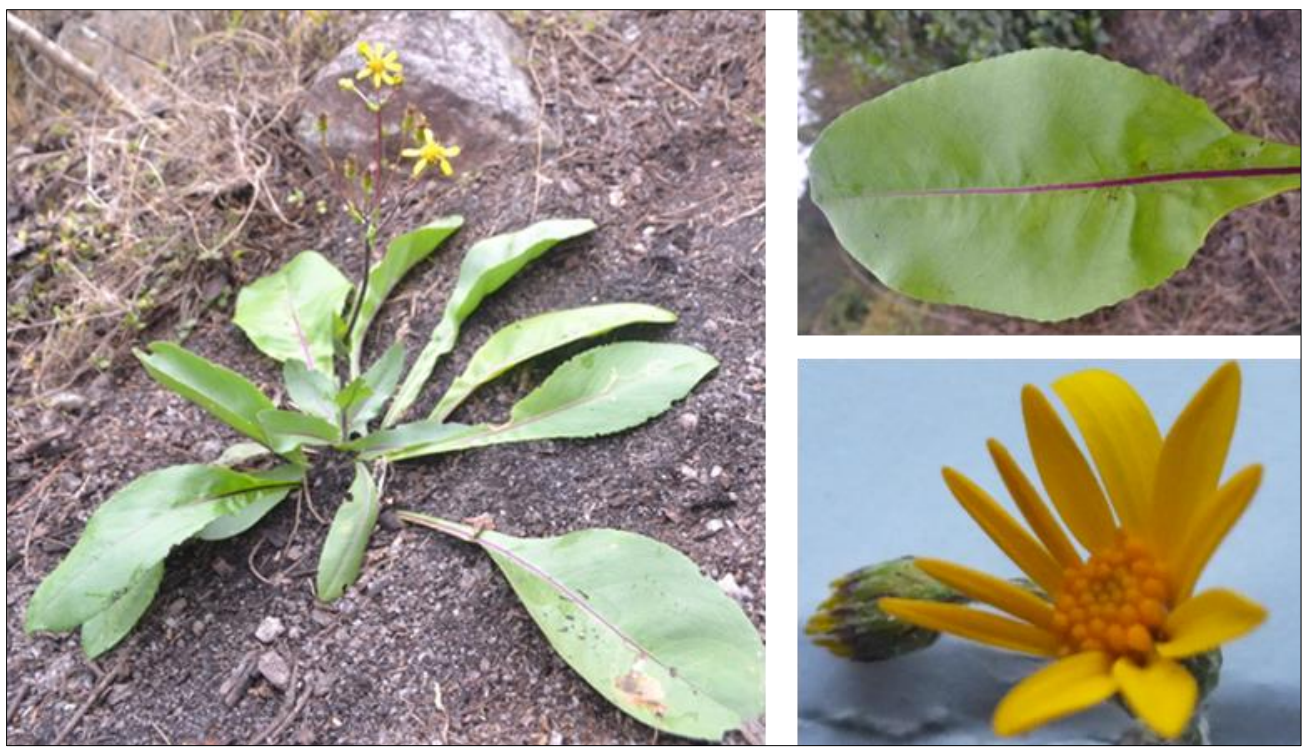

Figure 1 Senecio longiscapus Bojer. Source: The authors

\subsection{Microbial strains}

The microbial strains used were pathogens commonly sought in medical and food microbiological analysis and/or control. They include 4 Gram (-), 4 Gram (+) bacteria and one yeast (Table 1). 
Table 1 List of bacterial strains used

\begin{tabular}{|l|c|c|}
\hline \multicolumn{1}{|c|}{ Germ-tests } & Gram & Reference \\
\hline Listeria monocytogenes & + & ATCC 19114 \\
\hline Staphylococcus aureus & + & ATCC 6538 \\
\hline Clostridium perfringens & + & ATCC 13124 \\
\hline Bacillus cereus & + & ATCC 14579 \\
\hline Escherichia coli & - & ATCC 10145 \\
\hline Vibrio fischeri & - & ATCC 49387 \\
\hline Enterobacter aerogenes & - & ATCC 13048 \\
\hline Shigella flexneri & - & ATCC 12022 \\
\hline Yersinia enterocolitica & - & ATCC 23715 \\
\hline Candida albicans & & ATCC 10321 \\
\hline
\end{tabular}

\subsection{Animals}

OF-1 strain Albino mice (Mus musculus), weighing $25 \pm 2$ g, were provided by the Pasteur Institute of Madagascar (IPM) breeding farm.

\subsection{Extraction of the essential oil}

The extraction of the essential oils from the fresh leaves of Senecio longiscapus was carried out by hydrodistillation using a Clevenger type apparatus [15].

\subsection{Physico-chemical characterization}

The physico-chemical parameters to be determined and the references used are presented in Table 2.

Table 2 Parameters to determine and the standards used

\begin{tabular}{|l|c|}
\hline \multicolumn{1}{|c|}{ Parameters } & \multicolumn{1}{c|}{ Standards used } \\
\hline Relative density & AFNOR, NF-T 75-111 \\
\hline Refraction index & AFNOR, NF-T 75-112 \\
\hline Optical rotation & AFNOR, NF-T 75-13 \\
\hline Acid index & AFNOR, NF-T 75-103 \\
\hline Ester index & AFNOR, NF-T75-104 \\
\hline
\end{tabular}

\subsection{Essential oil analysis}

The chemical composition of the essential oil was determined by gas chromatography/mass spectrometry (GC/MS) [16]. The sample was analyzed using an AGILENT 5973 chromatograph (Network mass selective detector). It is equipped with a DBWAX column $(0.25 \mathrm{~mm} \times 30 \mathrm{~m} \times 0.25 \mu \mathrm{m})$. The temperature of the column was programmed from $40^{\circ} \mathrm{C}$ to $250^{\circ} \mathrm{C}$. The injector and detector temperatures are set at $280^{\circ} \mathrm{C}$. Helium is the carrier gas used, with a flow rate of $1 \mathrm{ml} /$ minute, the volume of sample injected being $1 \mu$ l. The peaks obtained were identified using AMDIS software Version 2.69 (Automated Mass Spectral Deconvolution and Identification System).

\subsection{Assessment of antimicrobial activity}

All the methods used for antimicrobial assay were detailed in our previous papers $[17,18]$. 


\subsection{Assessment of antimicrobial activity}

The sensitivity of microorganisms to the essential oil was determined by the agar diffusion method or aromatogram. Sterile paper disks ( $6 \mathrm{~mm}$ in diameter BioMérieux, REF 549916) were soaked with pure essential oil and placed on the surface of the inoculated Mueller-Hinton Agar (Scharlauß). The Petri dishes were incubated at $37^{\circ} \mathrm{C}$ for $24 \mathrm{~h}$ and the zones of inhibition were measured. The sensitivity to the essential oil was classified according to the diameter of the zones of inhibition as: not sensitive (-) for diameters less than $8 \mathrm{~mm}$; sensitive $(+)$ for diameters $9-14 \mathrm{~mm}$; very sensitive $(++)$ for diameters 15-19 mm and extremely sensitive (+++) for diameters larger than $20 \mathrm{~mm}$ [19].

Antibiotic and antifungal used as references in this study were respectively Neomycin $30 \mu \mathrm{g} /$ disk and Miconazole 500 $\mu \mathrm{g} /$ disk.

\subsection{Antioxidant activity determination}

The antioxidant capacity was evaluated by the method using free radical scavenging against DPPH (2, 2-Diphenyl-1Pycryl Hydrazyl). The method was detailed in previous paper [20].

\subsection{Toxicity determination}

A volume of $0.3 \mathrm{ml}$ of EO per $25 \pm 2 \mathrm{~g}$ of body weight was administered to mice by oral route by means of an intubation cannula with a curved distal. Four batches of 5 male mice were used. Another one receiving physiological serum (NaCl $0.9 \%$ ) was used as control. The mice were observed for $24 \mathrm{~h}$.

\section{Results}

\subsection{SLEO physico-chemical parameters}

The extraction yield and the physico-chemical parameters of SLEO are shown in Table 3.

Table 3 Extraction yield and physico-chemical parameters of SLEO

\begin{tabular}{|c|c|c|c|c|c|}
\hline Yield & Density & Refractive & Optical rotation & Acid index & Ester index \\
\hline $3 \%$ & 0.7466 & 1.4959 & $+3^{\circ} 47$ & 1.53 & 12.49 \\
\hline
\end{tabular}

\subsection{SLEO chemical composition}

The GC-MS analysis of the SLEO identified 17 constituents representing approximately 99.09\% of the overall composition. (Figure 2 and Table 4). Sabinene (53.28\%) is the main constituent and the major compounds were elemicin (15\%), $\beta$-pinene (9.85\%), methyleugenol (5.58\%), $\alpha$ - pinene (4.84) and mircene $(2.37 \%)$.

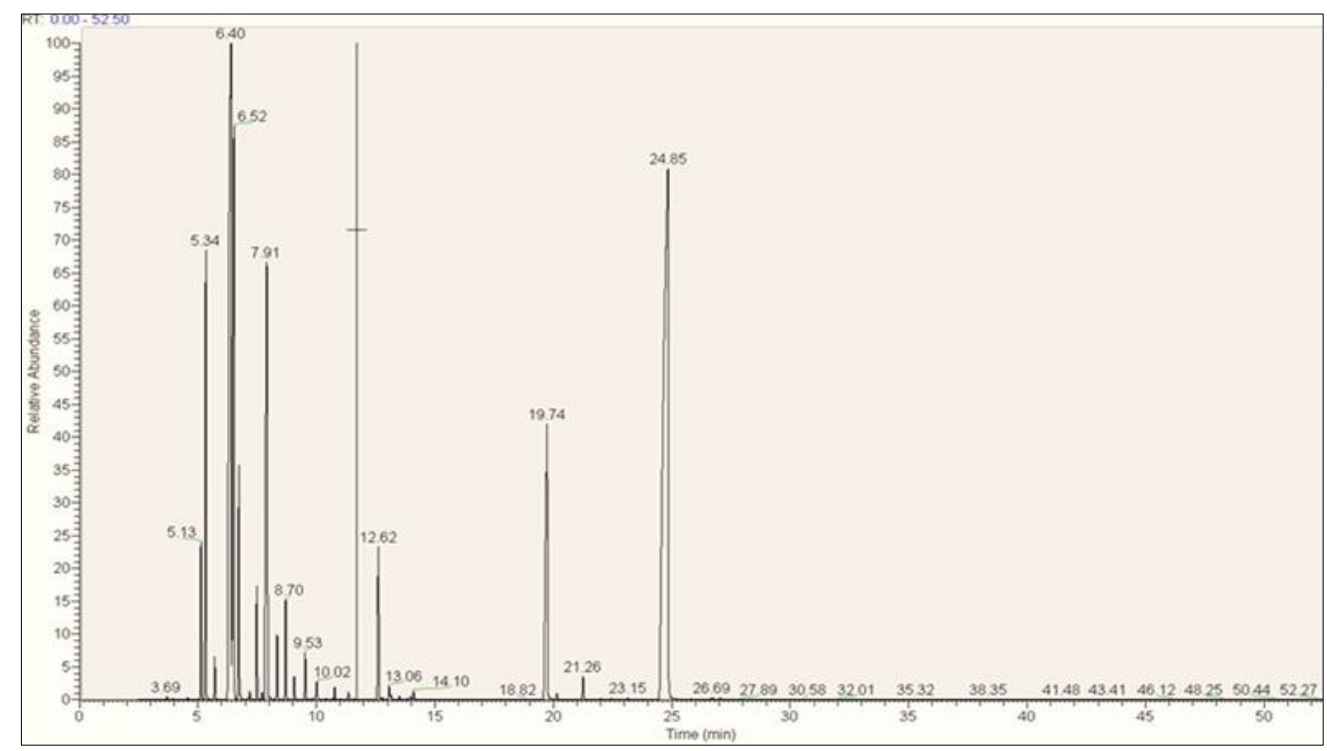

Figure 2 Chromatographic profile of SLEO 
Table 4 SLEO major components

\begin{tabular}{|c|c|c|c|}
\hline Peak number & Retention time (min) & Component & Relative rate $(\%)$ \\
\hline 1 & 5.1267 & $\alpha$-tujene & 1.32 \\
\hline 2 & 5.3370 & $\alpha$-pinene & 4.84 \\
\hline 3 & 5.7066 & camphene & 0.35 \\
\hline 4 & 6.4024 & sabinene & 53.28 \\
\hline 5 & 6.5222 & $\beta$-pinene & 9.85 \\
\hline 6 & 6.7294 & mircene & 2.37 \\
\hline 7 & 7.4816 & terpinolene & 0.97 \\
\hline 8 & 8.3441 & trans ocimene & 0.63 \\
\hline 9 & 8.7020 & $\gamma$-terpinene & 0.97 \\
\hline 10 & 9.0658 & trans sabinene hydrate & 0.33 \\
\hline 11 & 9.5273 & terpinolene & 0.46 \\
\hline 12 & 10.0223 & Linalol & 0.13 \\
\hline 13 & 12.6253 & terpinene-4-ol & 1.97 \\
\hline 14 & 19.7439 & methyleugenol & 5.58 \\
\hline 15 & 20.1727 & $\beta$-caryophyllene & 0.24 \\
\hline 16 & 21.2563 & $\alpha$-humulene & 0.80 \\
\hline 17 & 24.8396 & elemicin & 15 \\
\hline Total & & & 99.09 \\
\hline
\end{tabular}

\subsection{SLEO antimicrobial activity}

SLEO antimicrobial activity was tested at $745.2 \mathrm{mg} / \mathrm{ml}$ against nine strains of bacteria and one yeast. The IZs obtained are presented in the Table 5.

Table 5 Antimicrobial activity of SLEO

\begin{tabular}{|c|c|c|c|c|}
\hline \multirow[b]{2}{*}{ Strains } & \multicolumn{4}{|c|}{ Inhibition zone diameters (mm) } \\
\hline & $\begin{array}{l}\text { SLEO } \\
(7.45 \mathrm{mg} / \text { disk })\end{array}$ & $\begin{array}{l}\text { Strain } \\
\text { sensitivity }\end{array}$ & $\begin{array}{l}\text { Neomycin } \\
(30 \mu g / \text { disk })\end{array}$ & $\begin{array}{l}\text { Miconazole } \\
(500 \mu \mathrm{g} / \text { disk })\end{array}$ \\
\hline Listeria monocytogenes & 15 & ++ & 18 & \\
\hline Staphylococcus aureus & 20 & +++ & 19 & \\
\hline Clostridium perfringens & 18 & ++ & 24 & \\
\hline Bacillus cereus & 40 & +++ & 22 & \\
\hline Escherichia coli & 30 & +++ & 21 & \\
\hline Vibrio fischeri & 20 & +++ & 18 & \\
\hline Enterobacter aerogenes & 20 & +++ & 27 & \\
\hline Shigella flexneri & 12 & + & 26 & \\
\hline Yersinia enterocolitica & 12 & + & 27 & \\
\hline Candida albicans & 35 & +++ & & 25 \\
\hline
\end{tabular}


Based on the standard of Ponce et al, [19], SLEO was active on all microbial strains tested with IZs ranging from 12 mm (Shigella flexneri) to $40 \mathrm{~mm}$ (Bacillus cereus).

\subsection{SLEO antioxidant activity}

The antioxidant activities of SLEO and ascorbic acid are presented in Table 7 and figure 3.

Table 7 SLEO and ascorbic acid antioxidant activities

\begin{tabular}{|c|c|c|}
\hline Concentration $(\boldsymbol{\mu g} / \mathbf{m l})$ & \multicolumn{2}{|c|}{ Percentage* $^{*}$ of inhibition (\%) } \\
\hline 3.515 & 28.76 & 66.8 \\
\hline 7.03 & 57.19 & 71.97 \\
\hline 14.06 & 72.30 & 82.14 \\
\hline 28.125 & 73.52 & 86.48 \\
\hline 56.25 & 73.93 & 95.04 \\
\hline 112.5 & 79.52 & 99.03 \\
\hline 225 & 79.41 & 99.48 \\
\hline 450 & 79.62 & 99.41 \\
\hline 900 & 79.90 & 99.47 \\
\hline 1800 & 79.41 & 99.47 \\
\hline
\end{tabular}

*: Each value was the average of the values of 3 tests

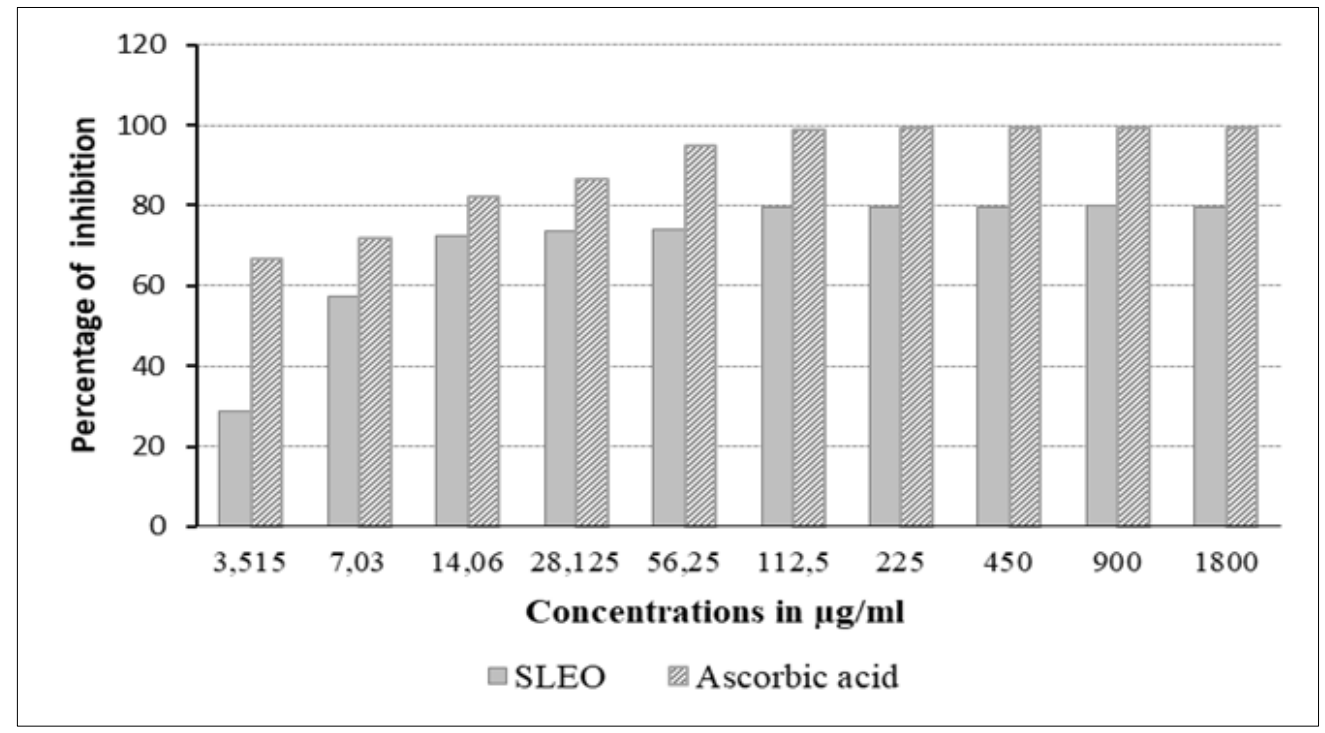

Figure 3 Effects of concentrations on the scavenging activity of SLEO and ascorbic acid against DPPH

For both SLEO and ascorbic acid, scavenging activity against DPPH increased with concentrations and the maximum of activity was reached at 112, $25 \mu \mathrm{g} / \mathrm{ml}$. The IC50s for SLEO and ascorbic acid were $4.601 \mu \mathrm{g} / \mathrm{ml}$ and $3.245 \mu \mathrm{g} / \mathrm{ml}$ respectively.

\subsection{SLEO toxicity}

Four increasing doses of SLEO $(1117.7,2235.5,4471.0$ and $8942 \mathrm{mg} / \mathrm{kg}$ ) were administered orally to 4 homogeneous batches of 5 mice of $25 \mathrm{~g} \pm 2$. Another batch of 5 mice serving as a control received physiological serum ( $\mathrm{NaCl} 0.9 \%$ ). No symptoms of intoxication were observed with the 4 doses tested during $24 \mathrm{~h}$. 


\section{Discussion}

The yields of essential oils are extremely variable depending on the plants considered, but they are generally very low, below 1\% [21]. The extraction yield of SLEO was much higher (3\%).

Seventeen (17) components representing 99.09\% of the overall composition were detected in SLEO. This quantity was close to that observed for example in S. giganteus (18) [22], S. argophylloides (16) and S. viridis (15) [23]. As shown in Table 8, the main components and their proportion (\%) in relation to the overall oil vary according to the species of Senecio. Sabinene, with a percentage of $53.28 \%$, was the main component of SLEO.

Table 8 Number of components detected and major components in different Senecio species

\begin{tabular}{|l|c|c|c|l|}
\hline \multirow{2}{*}{ Senecio species } & \multirow{2}{*}{ Plant part } & \multicolumn{2}{l|}{ Components } & \multirow{2}{*}{ Major components } \\
\cline { 3 - 5 } & & Number & $\mathbf{\%}$ & \\
\hline S. longiscapus & leaf & 17 & 99.09 & Sabinene (53.28\%) \\
\hline S. giganteus [22] & aerial part & 18 & 82.8 & $\begin{array}{l}\alpha \text {-pinene (19.4\%) and 6,10,14- } \\
\text { trimethyl-2-pentadecanone (19.1\%) }\end{array}$ \\
\hline S. vulgaris [24] & aerial part & 54 & 95.2 & $\alpha$-humulene (57.3\%) \\
\hline S. nemorensis [25] & flower & 76 & 86.8 & $\gamma$-curcumene (42.8\%) \\
\hline S. graciliflorus [11] & flower & 20 & 95.50 & $\alpha$-pinene (33.97\%) \\
\hline S. nudicaulis [4] & aerial part & 30 & 95.3 & caryophyllene oxide (24.99\%) \\
\hline S. flammeus [9] & aerial part & 48 & 98.41 & $\alpha$-farnesene (11.26\%) \\
\hline \multirow{2}{*}{ S. glaucus [8] } & flower & 33 & 97.1 & m-mentha-4,8-diene (31.4\%) \\
\cline { 2 - 5 } & shoot & 33 & 96 & m-mentha-1(7), 8-diene (25.6\%) \\
\hline S. subulatus [23] & aerial part & 20 & 95.5 & $\begin{array}{l}\text { p-cymene (33.3\%) and } \\
\text { (31.2\%) }\end{array}$ \\
\hline S. argophylloides [23] & aerial part & 16 & 99.8 & camphene (52.7\%) \\
\hline S. viridis [23] & aerial part & 15 & 94.8 & $\alpha$-thujene (31.7) \\
\hline
\end{tabular}

Sabinene does not seem to be common in the genus Senecio EOs. It is also the main component of the EO of S. graveolens aerial part (23.8\%) [10], but is present at much lower percentages in the EOs of S. polyanthemoides leaves (3.2\%) [26], S. flammeus (2.6\%) [9], S. mustersii aerial part (1.6\%) [10] and S. graveolens leaves (0.8\%) [27].

Although sabinene (53.28\%) was quantitatively by far the main component, other components such as elemicin (15\%), $\beta$-pinene (9.85\%), methyleugenol (5.58\%), $\alpha$-pinene (4.84) and mircene $(2.37 \%)$ were not negligible and might have important roles in the biological properties of SLEO.

According to the values of its physico-chemical parameters, SLEO was a light oil (density <1), clear and yellow, with a low refraction index (1.4959), dextrogyre $\left(+3^{\circ} 47\right)$, a low acid number (1.53) and an acid ester number of 12.49 .

SLEO, at $7.45 \mathrm{mg} /$ disk, exhibited high activity on $60 \%$ of the microorganisms tested, in particular on Bacillus cereus (IZ $=40 \mathrm{~mm})$, Candida albicans $(\mathrm{IZ}=35 \mathrm{~mm})$ and Escherchia coli $(\mathrm{IZ}=30 \mathrm{~mm})$. On several germs, SLEO was as active (on Staphylococcus aureus, Vibrio fischeri) or even much more active (on Bacillus subtilis, Escherchia coli, Candida albicans) than the reference antibiotics (Neomycin $30 \mu \mathrm{g} / \mathrm{disk}$ or miconazole $500 \mu \mathrm{g} / \mathrm{ml} / \mathrm{disk}$ ).

SLEO showed an antioxidant activity that increased with concentration and was maximal at $112.5 \mu \mathrm{g} / \mathrm{ml}$. Its efficacy was about 70\% of that of ascorbic acid. For comparison, the IC50s of the EOs from different parts of some Senecio species determined by the DPPH method assay and using ascorbic acid as standard reference are presented in Table 9. Based on the size of the difference between the EO and ascorbic acid IC50 values, SLEO has an antioxidant activity comparable to that of $S$. nudicaulis, higher than that of S. graciliflorus but significantly lower than that of S. glaucus. 
As mentioned in Table 9, several Senecio species are known to be dangerous to humans and animals. Therefore, before considering the exploitation of the interesting biological properties already identified, it was necessary to evaluate the toxicity of SLEO. Acute toxicity tests on mice showed that at a dose as high as $5 \mathrm{~g} / \mathrm{kg}$ body weight by the oral route, SLEO did not cause any symptoms of intoxication for 24 hours. This result is in agreement with our field surveys that no adverse effects due to the use of $S$. longiscapus have been reported. This is an important advantage as it does not limit the uses of SLEO, especially for therapeutic purposes. However, this result should be complemented by further toxicity tests.

Table 9 Comparison of the IC50s of EOs of some Senecio species and ascorbic acid determined by the DPPH scavenging method

\begin{tabular}{|c|c|c|c|}
\hline \multicolumn{2}{|c|}{ Senecio } & \multicolumn{2}{|c|}{$\mathrm{IC} 50(\mu \mathrm{g} / \mathrm{ml})$} \\
\hline Species & Plant part & EOs & Ascorbic acid \\
\hline S. longiscapus & leaf & 4.601 & 3.245 \\
\hline \multirow{2}{*}{ S. graciliflorus [11] } & flower & 21.6 (flower) & \multirow{2}{*}{14.3} \\
\hline & leaf & 24.8 & \\
\hline \multirow{2}{*}{ S. glaucus [8] } & flower & 1.6 & \multirow{2}{*}{16} \\
\hline & shoot & 1.9 & \\
\hline S. nudicaulis [4] & aerial part & 10.61 & 12.08 \\
\hline
\end{tabular}

Other known biological properties of components that are among the main components in SLEO should be explored. Its non-toxicity, good antimicrobial and antioxidant activities could make SLEO an alternative in the treatment of infectious diseases.

\section{Conclusion}

The chemical composition and physicochemical characteristics of the essential oil of Senecio longiscapus leaves are well established. Two important pharmacological properties, antibacterial and antioxidant, and the absence of toxicity of the essential oil have been demonstrated. The results obtained on the antimicrobial activity of SLEO provided scientific basis of the use of Senecio longiscapus in traditional medecine.

\section{Compliance with ethical standards}

\section{Acknowledgments}

We sincerely acknowledged the Pasteur Institute of Madagascar (IPM) for providing us with the experimental animals.

\section{Disclosure of conflict of interest}

The authors declare no conflict of interests.

\section{Statement of ethical approval}

All the tests on animals were approved and in line with the standard established by Ethics Committee of Pasteur Institute of Madagascar.

\section{References}

[1] Noudogbessi J-P, Kossou D, Sohounhloué DCK. Composition chimique et propriétés physico-chimiques des huiles essentielles de Pimenta racemosa (Miller) et de Chromolaena odorata (L. Robinson) Acclimatées au Bénin. Journal de la Société Ouest-Africaine de Chimie. 2008; 026: 11-19.

[2] Schatz GE. Generic Tree Flora of Madagascar. Kew: Royal Botanic Gardens, ISBN: 9781900347822. $2001 ; 490$. 
[3] Albayrak S, Aksoy A, Hamzaoglu E, Ekici L, Budak Ut. Antimicrobial and antioxidant activities of Senecio species growing in the Black Sea region, Turkey, Acta Botanica Gallica. 2008; 155(3): 447-456.

[4] Sharma P, Shah GC. Composition and antioxidant activity of Senecio nudicaulis Wall. ex DC. (Asteraceae) a medicinal plant growing wild in Himachal Pradesh, India. Natural Product Research. 2015; 29(9): 883-886.

[5] Humbert H. Flore de Madagascar et des Comores. Tome II: 189ème Famille : Composées. 1962; 440-450.

[6] Ramavovololona. Biogéographie des Senecio (Asteraceae) de Madagascar. Biogéographie de Madagascar. 1996; 165-170.

[7] Kenoufi M. Caractérisation histologique, caryologique, phytochimique et activités biologiques de Senecio giganteus Desf et $S$. jacobaea L. Doctorat 3ème cycle, Spécialité: Valorisation et protection de la biodiversité végétale. Université Ferhat Abbas Sétif. 2015; 1: 127.

[8] Ramadan T, Zaher A, Amro A, Sultan R. Chemical composition and biological activity of capitula and shoots essential oils of Senecio glaucus L. Journal of Essential Oil Bearing Plants. 2020; 23(1): 168 -183.

[9] Xiao Kai-Jun, Wang Wen-Xia, Dai Jia-Li, Zhu Liang. Anti-inflammatory activity and chemical composition of the essential oils from Senecio flammeus. EXCLI Journal. 2014; 13: 782-791.

[10] Arancibia L, Naspi C, Pucci G, Arce. Aromatic plants from Patagonia: chemical composition and antimicrobial activity of the essential oil of Senecio mustersii and S. subpanduratus. Boletín Latinoamericano y del Caribe de Plantas Medicinales y Aromáticas. 2010; 9(2): 123-126.

[11] Lone SH, Bhat KA, Bhat HM, Majeed R, Anand R, Hamid A, Khuroo MA. Essential oil composition of Senecio graciliflorus DC: comparative analysis of different parts and evaluation of antioxidant and cytotoxic activities. Phytomedicine. 2014; 21(6): 919-925.

[12] Johnson AE, Molyneux RJ, Ralphs MH. Senecio: A Dangerous Plant for Man and Beast. RANG ELANDS. 1989; 11(6): 264-264.

[13] Stegelmeier BL. Pyrrolizidine alkaloid-containing toxic Plants (Senecio, Crotalaria, Cynoglossum, Amsinckia, Heliotropium, and Echium spp. Veterinary Clinics of North America - Food Animal Practice. 2011; 27: 419-428.

[14] Dimande AFP, Botha CJ, Prozesky L, Bekker L, Rösemann GM, Labuschagne L, Retief E. (2007). The toxicity of Senecio inaequidens DC. Journal of the South African Veterinary Association. 78(3): 121-129.

[15] Clevenger JF. Apparatus for the determination of volatile oil. The Journal of the American Pharmaceutical Association (1912). 1998; 17(4): 345-349.

[16] Arpino P, Prevot A, Tranchant J, Vergnol A, Witier P. Manuel pratique de chromatographie en phase gazeuse. Paris: Masson. 1995.

[17] Andriamampianina HL, Rakoto DAD, Petit T, Ramanankierana H, Randrianarivo HR, Jeannoda VL. Antimicrobial activity of extracts from Crotalaria bernieri Baill. (Fabaceae). African Journal of Microbiology Research. 2016; 10(3): 1229-1239.

[18] Randriamampianina LJ, Razafintsalama VE, Rakoto DAD, Randrianarivo HR, Jeannoda VL. Antimicrobial activity of seed extracts from Albizia bernieri E. Fourn. (Fabaceae). Journal of Pharmacy and Biological Sciences. 2017; 12(3): $72-7$.

[19] Ponce AG, Fritz R, del Valle C, Roura SI. Antimicrobial activity of essential oils on the native microflora of organic Swiss chard, Lebensmittel-Wissenschaft und -Technologie-LWT. 2003; 36: 679-684.

[20] Solofomalala AHD, Randriamampianina LJ, Randrianarivo HR, Rakoto DAD, Jeannoda VL. Antimicrobial and antioxidant activities of the fruits of bemavo, a variety of Ravenala madagascariensis Sonn. (Strelitziaceae). World Journal of Biology Pharmacy and Health Sciences. 2020; 02(02): 030-039.

[21] Laguerre V. Huiles essentielles et 1.8-cinéole. Sciences pharmaceutiques. hal-01770640. 2015.

[22] Chibani S, Gherboudj W, Kabouche A, Touzani R, Aburjai T, Kabouche Z. GC-MS analysis of Senecio giganteus Desf. from Algeria. Journal of Essential Oil Bearing Plants. 2013; 16: 123-125.

[23] Dambolena JS, Zunino MP, Banchio E, Lucini EI, Biurrun FN, Rotman A, Ahumada 0, Zygadlo JA. Essential oil composition of three species of Senecio from Argentina. Journal of essential oil-bearing plants. 2008; 11(6): 623 $-627$. 
[24] Andreani S, Paolini J, Costa J, Muselli A. Essential-oil composition and chemical variability of Senecio vulgaris L. from Corsica. Chemistry and Biodiversity. 2015; 12(5): 752-66.

[25] Üçüncü O, Kahriman N, Terzioglu S, Karaoglu SA, Yayh N. Composition and antimicrobial activity of the essential oils from flowers of Senecio othonnae, A. racemosus, and S. nemorensis. Natural Product Communications. 2010; 5(5): 831-834.

[26] Oladipupo LA, Adebola 00. Chemical composition of the essential oils of the flowers, leaves and stems of two Senecio polyanthemoides Sch. Bip. Samples from South Africa. Molecules. 2009; 14: 2077-2086.

[27] Pérez C, Agnese AM, Cabrera JL. The essential oil of Senecio graveolens (Compositae): chemical composition and antimicrobial activity tests. Journal of Ethnopharmacology. 1999; 66: 91-96. 